\title{
Comparison of Speech Motor Function, Articulation, and Phonological Characteristics of Children with and without Palatine Tonsil Hypertrophy: A Follow-Up 7 Months after Tonsillectomy
}

\author{
Yunkyung Song \\ Department of Communication Disorders, Tongmyong University, Busan, Korea
}

Correspondence: Yunkyung Song, PhD Department of Communication Disorders, Tongmyong University, 428 Sinseon-ro, Nam-gu, Busan 48520, Korea

Tel: +82-51-629-2128

Fax: +82-51-629-2019

E-mail: voicesyk@hanmail.net

Received: October 5, 2016

Revised: November 10, 2016

Accepted: November 17, 2016

This work was supported by the National Research Foundation of Korea Grant funded by the Korean Government (NRF-2013S1A5A8024867).

\begin{abstract}
Objectives: In a previous study, the diadochokinesis (DDK) and the percentage of consonants correct $(\mathrm{PCC})$ of children with palatine tonsil hypertrophy $(\mathrm{TH})$ were significantly lower than those of typically developing children (TD), and the number of children who produced phonological processes (PP) was significantly higher in TH than in TD. And there were no significant changes in PCC and PP at 6 weeks after tonsillectomy. So, the purpose of this study was to compare the values (DDK, PCC, PP) in children 7 months after tonsillectomy (AT) and TD. Methods: Twenty-seven AT and 29TD were measured for DDK and the Assessment of Phonology and Articulation for Children (APAC). An independent $t$-test and $\chi^{2}$-test were conducted to determine whether there were significant differences between the groups. Three children who had lower PCC than their peer group were given individual speech therapy. Results: There were no significant differences in DDK, PCC, and PP between AT and TD. Except for one child, the children improved in PCC and PP after speech therapy. Conclusion: The results suggested that AT can catch up with TD. But there were individual differences in improvement of PCC and PP at 7 months after tonsillectomy and after speech therapy. It is necessary for a follow-up study to examine the timing of tonsillectomy and necessity of speech therapy after tonsillectomy.
\end{abstract}

Keywords: Palatine tonsil hypertrophy, Tonsillectomy, Diadochokinesis, Percentage of consonants correct, Phonological process
말소리장애를 유발하는 요인은 뇌성마비와 같은 중추신경계 질 환이나 구개열과 같은 심각한 구조적 결함, 지적 장애 등 다양하게 존재한다. 그리고 이와 같은 원인을 동반하고 있는 아동들은 일반 아동들과 다른 특성을 나타낼 것으로 예측하기 용이한 까닭에, 말소 리 발달이나 그 특성에 관한 연구들이 이어져왔다( $\operatorname{Han} \& \mathrm{Sim}, 2008$; Han, Sung, Sim, \& Lee, 2013; Kim, 2009; Moon \& Ha, 2012). 그러나 혀의 길이나 크기, 교합의 문제, 구개의 높이나 구강 감각 변별 능력 등은 비교적 드러나지 않는 요인들이며, 그 이유로 이와 같은 요인과 연관된 말소리 산출 특성에 대한 연구는 흔하지 않은 편이다(Bernthal \& Bankson, 2004). 구개편도비대 역시 이처럼 쉽게 드러나지 않 는 요인 중 하나이지만, 안산 지역의 한 초등학교 학생 전수조사에서
만 6 세 아동의 $28 \%$ 가 구개편도비대가 있는 것으로 확인되어, 아동에 서높은 빈도를 보이는 질환임을 알수 있었다(Chae et al., 2000).

이처럼 아동에게 높은 출현율을 보이는 구개편도비대는 말소리 길의 변화를 초래하고, 혀 뒷부분의 움직임을 방해할 수 있기 때문 에 말소리 산출에 직접적인 영향을 미칠 가능성이 있다. Singh, Gathwala, Pathania, Singh과 Yadav (1994)와 Salami, Jankowska, Dellepiane, Crippa와 Mora (2008)는 구개편도비대가 있는 아동의 말소 리 특성 또는 편도절제술 전후의 말소리 특성을 비교하였으며, 그 결 과 이 아동들은 연구개음을 치경음으로 대치하거나 치경음 $/ \mathrm{s}, \mathrm{r}, \mathrm{l}, \mathrm{d}$, $\mathrm{n}, \mathrm{t} /$ 를 치간음화 시키는 오류가 있음을 보여주었다. 그러나 국내 말 소리 관련 연구들 중에는 구개편도비대와 관련된 보고를 찾아보기 
어렵다. 이에 저자는 1 차 연구로 구개편도비대 아동이 일반 아동에 비하여 말운동 기능, 자음정확도, 음운변동의 특성에 차이가 있는 지, 그리고 편도절제술 전후로 이와 같은 측면에 변화가 있는지 비교 하여 보았다(Song, 2014). 연구 결과, 구개편도비대 아동은 일반 아 동에 비하여 길항반복운동이 더 느리고, 자음정확도가 더 낮으며, 더 다양한 음운변동을 더 많은 아동들이 나타내는 것을 알 수 있었 다. 또한 편도절제술 6주 후, 구개편도비대 아동의 길항반복운동 소 요시간은 일반 아동과 유사하게 변화되었으나, 자음정확도는 의미 있는 변화를 보이지 못하였고, 이는 음운변동 역시 마찬가지였다.

구개편도비대 아동들의 수술 전 길항반복운동 소요시간이 일반 아동에 비하여 오래 걸린 점은 Valera 등(2003)이 제시한 경향, 즉 구개편도비대로 인한 상기도 폐쇄의 지속은 아동들의 위, 아래 입 술과 혀와 볼 근육의 근긴장을 감소시키는 것 같다는 결론을 지지 해주었다. 그러나 편도절제술 6주 후 측정치에서는 일반 아동과 유 의한 차이가 없었는데, 이는 수술 후 6주간의 비교적 짧은 기간 동 안 관련 근육의 근긴장이 강화되었거나, 또는 말소리 길과 관련된 물리적 제약의 해결로 말운동 기능이 일반 아동과 유사한 수준으 로 개선된 것으로 해석할 수 있었다. 일반 아동에 비하여 유의하게 낮은 점수를 보였던 자음정확도는 편도절제술 6주 후에도 여전히 유의한 변화를 보이지 못하였으며, 이러한 특성은 음운변동의 종 류와 횟수에서도 마찬가지였다. 이 연구에서 구개편도비대 아동들 이 일반 아동들에 비하여 유의한 차이를 보이며 더 많이 보인 음운 변동은 치조마찰음의 치간음화, 파찰음화·경구개음화, 전형적 어 중 단순화였다. 이를 통하여 구개편도비대 아동은 혀를 앞으로 내 밀어 발음하는 경향이 있고 어중종성을 생략하거나, 어중초성의 조음장소에 역행동화 시키는 경우가 많다는 것을 알 수 있었다. 그 리고 이와 같은 특성이 구개편도를 제거하여 말소리 길의 장애물 을 없앤 후에도 지속되고 있다는 점은 구강공간의 변화가 찾아와 도 자음산출을 정확하게 해주는 변화까지 이끌어 내지는 못하였 거나, 아니면 유의한 변화를 보이기 위해서는 보다 더 많은 시간이 필요할 수 있다는 점을 의미하는 것으로 해석할 수 있었다.

Valera, Trawitzki와 Anselmo-Lima (2006)는 편도절제술 이후2 년간 안면 자세, 근 긴장도, 저작, 삼킴, 호흡 등과 관련된 근기능 평 가를 시행하였는데, 수술 후 첫 6 개월이 되어서야 수술 전후의 수 치에 유의한 변화가 나타나는 것을 보여주었다. 이와 같은 결과는 구개편도비대 아동이 편도절제술 후 6주보다 더 긴 시간 후에 말소 리 산출에 변화를 보일 수 있음을 고려하게 하였다. 이에 저자는 편 도절제술 6 주 후의 특성이 장기적으로 지속되는지, 6 개월 이상의 시간 후에는 다른 변화가 나타나는지, 변화가 나타난다면 또래의 일반 아동과 유사해지는지 알아보고자 하였다. 이를 위하여 2 차 연
구로 편도절제술 후 7개월이 지났을 때 말운동 기능 및 조음음운 특성을 일반 아동과 비교하여 살펴보고자 하였다. 또한 수술 후 7 개월이 지난 후에도 자음정확도와 음운변동 특성이 또래 일반 아 동 수준에 미치지 못하는 아동이 있다면 언어치료를 통해 의미 있 는 개선을 나타내는지 살펴보기로 하였다.

연구문제는 다음과 같다.

1) 편도절제술 7 개월 후 구개편도비대 아동은 일반 아동과 비교 하였을 때 말운동 기능, 자음정확도, 음운변동의 종류와 빈도에 차 이를 보이는가?

2) 편도절제술 7개월 후 구개편도비대 아동의 말운동 기능은 자 음정확도와상관이 있는가?

3) 수술 후 조음음운 오류가 지속되는 아동의 경우, 3 개월 이상 의 언어치료 후에 자음정확도 및 음운변동의 종류와 빈도에 차이 를 보이는가?

\section{연구 방법}

\section{연구 대상}

1 차 연구에서는 만 5-6세의 아동으로 연령과 성별의 비율이 유 사한 일반 아동 40 명과 구개편도비대 아동 40 명이 대상이었다. 2 차 연구인 본 연구에서는 피험자의 탈락이 있어 대상자 수에 변동이 생겼다. 일반 아동과 구개편도비대 아동 모두 초기 평가 후 약 7개 월의 시간이 흐른 후 재평가를 실시하였기 때문에 이사 및 연락 두 절 등으로 실험 집단 아동은 총 27 명(남아 19 명, 여아 8 명), 통제 집 단 아동은 총 29 명(남아 20 명, 여아 9 명)으로 피험자의 감소가 있었 다. 새로운 피험자를 포함시킬 수 있는 없는 후속 연구이므로, 부모 와 유치원 교사의 보고에 의하여 두 집단 모두 발달장애, 감각장애, 정서장애가 없고, 지능이 정상으로 판단되어 선행연구에 참여했던 대상 아동들 중 연락이 유지되고 있는 아동들만이 참여하게 되었 다. 본 연구에 참여한 구개편도비대 아동 집단과 일반 아동 집단의 생활연령과 수용어휘력 차이 유무를 판단하기 위하여 $t$-검정으로 비교해본 결과, 두 집단에 유의한 차이는 없었으며(Table 1), 두 집 단의 성별 분포에 차이가 있는지 $\chi^{2}$ 검정을 실시한 결과 유의한 차

Table 1. Participants' characteristics

\begin{tabular}{lccc}
\hline Characteristic & AT group (N=27) & TD group (N=29) & $t$ \\
\hline Age (mo) & $76.63(9.15)$ & $75.79(4.99)$ & .420 \\
Receptive vocabulary $^{\text {a }}$ & $76.67(17.27)$ & $79.90(11.76)$ & -.823 \\
\hline
\end{tabular}

Values are presented as mean (SD).

$\mathrm{AT}=$ children 7 months after tonsillectomy; TD = typically developing children.

aReceptive \& expressive vocabulary test (Kim, Hong, Kim, Jang, \& Lee, 2009). 
이가 없는 것으로 나타났다 $\left(\chi^{2}=.000, p=1.000\right)$.

\section{평가 과제}

말운동 기능

말운동 기능 평가를 위하여 1 차 연구와 동일하게 길항반복운동 과제를 실시하였다. 길항반복운동(diadochokinesis, $\mathrm{DDK}$ ) 과제는 일반적으로 정해진 시간 동안 일정 음절반복의 횟수를 측정하거 나, 정해진 횟수만큼 반복하는 동안 소요된 시간을 재게 되는데, 본 연구에서는 1 차 연구와 같은 후자의 방법으로 실시하였다. 자극어 역시 1차 연구와 같이 Song과 Sim (2008)의 경우와 유사하게 격파 열음과 모음 'ㄱ'를 결합한 음절들을 사용하였다. 1 음절 자극어 /퍼/, /터/, /커/와 3음절 자극어/퍼터커/ 외에 조음기관 구조.기능 선별검사(SMST; Shin, Kim, Lee, \& Lee, 2010)의 검사 항목인 /긍/ 과 /러/ 역시 동일하게 사용하였다. 마찬가지로 1음절의 경우 15 회 반복하는데 걸리는 시간을 측정하였고, 3 음절의 경우 1 음절 반복 과 같은 음절수를 반복하도록 총 5 회 반복에 걸리는 시간을 측정하 여 실험 집단과 통제 집단을 비교하였다.

\section{자음정확도}

자음정확도 평가를 위하여 1 차 연구와 동일하게 아동용 발음평 가(APAC; Kim, Pae, \& Park, 2007)를 실시하였고 정조음한 자음의 수를 파악하여 자음정확도를 구하였다. 1 차 연구와 마찬가지로 대 치오류뿐 아니라 왜곡오류 또한 조음오류에 포함시켰다.

\section{음운변동}

아동용 발음평가(APAC)의 낱말 검사에서 대상 아동들이 산출 한 낱말 자료로 오류패턴을 분석하여 음운변동을 파악하였다. 1 차 연구와 동일하게 검사도구에 제시되어 있는 전체단어 변동(음절 생략.축약, 어말종성 생략, 반복-자음조화, 전형적 어중 단순화, 비 전형적 어중 단순화, 어두초성생략, 첨가, 도치.이동)과 음소변화 변 동(긴장음화·탈기식음화, 이완음화, 기식음화, 유음의 비음화·파열 음화, 유음의 단순화, 파찰음-마찰음의 파열음화, 파찰음화.경구 개음화, 탈비음화, 마찰음화, 연구개음의 전설음화, 양순음화, 연구 개음화, 성문음화, 치조마찰음의 치간음화, 파찰음의 치간음화, 치 조마찰음의 설측음화)으로 분류하여 음운변동을 분석하고, 두 집 단의 음운변동 종류와 빈도를 비교하였다.

\section{연구 절차}

자료 수집

1 차 연구의 후속 연구인 본 연구는 일반 아동 집단의 경우 초기
평가에서 7 개월 후에, 구개편도비대 아동 집단의 경우 각 아동이 편 도절제술을 받은 지 7 개월 후에 후속 자료 수집을 진행하였다. 편도 절제술을 받은 아동은 수술 후 6주 평가를 받으면서 약속하였던 술 후 7개월이 되는 날에 수술을 받은 A 종합병원의 이비인후과 외 래 언어치료실에 방문하여 평가를 받았다. 일반 아동들은 초기 평 가 일에서 7 개월 후에 동일 유치원인 B 유치원에서 평가를 받았다. 2 차 연구의 재평가 시에도 두 집단의 아동들은 보호자의 동의 하 에 말운동 기능검사와 조음음운검사를 받았다. 재평가 시기를 수 술 후 7 개월로 정한 것은 편도절제술 후 첫 6 개월이 지나서야 안면 자세, 근 긴장도, 저작, 삼킴, 호흡 등과 관련된 근기능에 유의한 차 이가 나타났다는 Valera 등(2006)의 연구 결과를 참고하였기 때문 이다. 다만 수술 직후로부터 6 개월이 흐른 뒤가 아니라, 1 차 연구에 서 참고하였던 수술 부위의 통증이 사라지고 정상적인 식사가 가 능할 때까지 걸리는 시간인 4주(Lee, 2009)로부터 6개월이 지난 시 기인 수술 후 7개월에 재평가를 하였다. 재평가는 두 집단 모두 진 행에 방해가 되지 않는 조용한 방에서 한 명씩 실시하였다. 구개편 도비대 아동들은 소속 병원의 언어치료실에서 보호자 상담 및 아 동 평가가 이루어졌으며, 일반 아동들은 오전 수업 중에 유치원의 조용한 빈 방으로 한 명씩 이동하여 평가가 이루어졌다.

\section{검사 방법}

2차 연구의 재평가에서도 조음기관 구조.기능 선별검사(SMST) 를 먼저 실시하여 대상자 조음기관의 구조적 특징을 파악하고, 그 후 $\mathrm{DDK}$ 과제와 조음음운검사를 실시하였다. 1 차 연구에서와 마찬 가지로 $\mathrm{DDK}$ 과제와 아동용 발음평가(APAC)의 전 과정은 디지털 녹음기와 디지털 캠코더로 녹음 및 녹화하였다. 이는 음성파일로 광대역 스펙트로그래프를 그려 $\mathrm{DDK}$ 과제에 소요된 시간을 정확 하게 파악하기 위함과 동시에, 발화 내용을 반복하여 들으면서 정 확히 전사하기 위해서였다. 또한 검사 후 발화 내용을 전사할 때, 영 상을 재생시키며 정확한 입 모양과 혀의 자세를 확인하기 위함이었 다. 구개편도비대 아동의 말소리 평가 시, 그 입과 혀의 모양과 위치 를 확인하는 것이 중요하기 때문이다.

$\mathrm{DDK}$ 과제의 경우도 1 차 연구에서와 동일한 방법으로 평가를 진 행하였다. 대상 아동에게 각 목표 음절을 최대한 빠르고 정확하게 산출하게 하였다. 1음절 내에서는 무작위 순서로 산출하도록 하고 그 후에 3 음절 과제를 이어서 실시하였다. 각 과제를 시작하기 전, 1 차 연구와 동일하게 “이제부터 ** 말소리를 할 수 있는 한 가장 빠르 게 반복하는 거야. 가장 빨리 해야 하지만 소리가 정확해야 돼. 선생 님이 '시작'하면 시작해서, ‘그만' 할 때까지 계속하는 거야.” 라고 지시하였다. 연구자가 먼저 각 과제에 대한 시범을 보인 후 대상자 
와 연구자가 함께 빠르고 정확하게 반복 산출하는 것을 연습하였 다. 각 목표 음절은 모두 3회씩 반복 측정하였으며, 그 평균치를 계 산하여 분석하였다.

아동용 발음평가(APAC)의 경우도 1 차 연구와 동일한 방법으로 실시하였다. 검사 도구에 들어있는 그림판을 이용하여 이름대기를 유도하였으며, 아동이 자발적인 반응을 하지 않거나 오반응을 하 였을 경우, 의미적, 상황적 단서를 제공하여 목표 단어를 유도하였 다. 적절한 반응이 나오지 않을 경우, “이건 00 야. 이게 뭐라고?”라 고 하여 간접 모방을 유도하였다.

\section{조음 치료 진행}

편도절제술 후 7개월이 흐른 뒤 조음음운평가에서 또래 연령에 비하여 낮은 자음정확도와 지연된 음운변동을 보인 아동의 조음 치료를 시행하였다. 치료가 필요할 것으로 여겨지는 아동 중에서 보호자가주 1-2회의 치료에 참여하기를 희망한 아동 세 명(치료 아 동 1 , 치료 아동 2 , 치료 아동 3 )의 치료를 진행하였으며, 조음음운 장애 치료경력이 3 년 이상인 언어치료사 1 인이 세 명의 아동을 치 료하였다. 치료에 들어가기 전 기초선을 구하기 위하여 3 회 이상 세 아동의 APAC 평가를 각각 반복 시행하였다. 그 후 보호자와 협의 하여 편도절제술을 시행 받았던 $\mathrm{A}$ 종합병원 이비인후과 외래의 언 어치료실에서 주 1-2회 정기적인 개별치료를 실시하였다. 1 차 연구 결과 구개편도비대로 인한 말소리 길의 변형이 조음기관, 특히 혀의 전방화에 영향을 미친 것 같다고 판단되었으며, 그 외에도 조음기 관의 위치나 정확한 조음방법에 오류가 있는 것으로 여겨져 음운 론적 접근법보다 전통적 접근법이 적절한 것으로 생각되었다. 따라 서 치료는 조음점 지시법, 점진적 접근법, 청각적 자극과 모방 등 주 로 오류 음소의 산출을 촉진하여 지연된 음운변동을 소거해 나가 는 전통적 치료 기법을 사용하였다(Kim \& Shin, 2015). 치료는 최 소 3 개월 이상 실시하였으며, 보호자가 원하거나 치료가 더 필요한 경우는 그 이상 지속하였다.

\section{측정 및 분석 방법}

수집된 $\mathrm{DDK}$ 자료의 분석은 1 차 연구와 동일하게 광대역 스펙트 로그래프를 그려서 1 음절 15 회와, 3 음절 5 회에 소요된 시간을 구하 였다. 컴퓨터에 Multi-Speech Model 3700 (Kay-Pentax)을 탑재하 여 Multi-Speech Main Program을 구동시킨 후, 수집된 자료의 음 성파일을 열어 광대역 스펙트로그래프를 그렸다. 각 평가 자료의 스펙트로그래프를 그려 1 음절 15 회와 3 음절 5 회에 소요된 시간을 구했다. 각 검사 항목마다 3 회 수행 자료의 소요시간을 각각 구하 고, 평균 $\mathrm{DDK}$ 소요시간을 구하였다.
자음정확도 역시 1 차 연구와 동일하게 분석하였다. 아동용 발음 평가(APAC)의 기록 방식에 따라 기록한 뒤, 생략, 첨가, 대치, 왜곡 을 모두 오류로 채점하여 두 집단을 비교하였다. 연구의 목적을 아 는 경우 전사 및 $\mathrm{APAC}$ 분석 결과에 영향을 미칠 수 있으므로, 연구 자뿐 아니라 연구의 목적을 모르는 10 년 이상 경력의 언어치료사가 같은 자료를 전사하고 분석한 뒤, 일치하지 않는 부분은 합의를 거 쳐 자음정확도와 음운변동을 정리하였다. 음운변동은 전체단어 변동과 음소변화 변동으로 나누어 분석하고, 그 종류와 빈도를 구 하여 비교하였다.

\section{통계 처리}

통계 처리는 SPSS Statistics ver. 23 (IBM, Armonk, NY, USA)을 사용하였다. 통계 처리 역시 1 차 연구와 동일하게 두 집단의 길항반 복운동에 걸린 소요시간과 자음정확도는 독립된 두 집단 $t$-검정을 실시하여 비교하였다. $\mathrm{APAC}$ 의 음운변동 분석 역시 1 차 연구에서 처럼 도구에서 제시하는 기준인 적어도 3 회 이상 출현한 음운변동 만으로 분석하였다. 음운변동의 경우는 평균비교보다 출현한 아동 의 수를 비교해야 하므로 $\chi^{2}$-검정을 시행하였다. 각 변인들의 상관 은 Pearson 상관계수를 구하여 살펴보았으며, 통계학적 의의는 $p$ 값 이 .05 이하일 경우로 정의하였다. 한편, 수술 후 조음음운 오류가 지속되는 아동의 언어치료 전후 자음정확도 변화는 치료받은 아동 의 수가 3 명으로 적고 집단 비교가 어려운 조건이므로 각 아동의 기초선 자료 및 치료 진행 중 자료, 그리고 치료 후 유지 단계의 자료 를 그래프로 제시하여 그 변화를 시각적으로 확인할 수 있도록 하 였다. 또한 각 아동에게 나타난 음운변동의 종류와 횟수는 표에 정 리, 제시하여 그 변화를 알 수 있도록 하였다.

\section{신뢰도}

전체 낱말 발화자료에서 연구자와 연구자 외 언어치료사의 전사 일치도는 $90.6 \%$ 였으며, 길항반복운동 자료의 $10 \%$ 에 해당하는 소요 시간의 평가자 간 신뢰도는 $92.2 \%$ 로 나타났다. 합의를 거친 전체 전 사자료의 $10 \%$ 에서 계산한 자음정확도의 평가자 간 신뢰도는 $100 \%$, 음운변동의 평가자 간 신뢰도는 $98.6 \%$ 였다.

\section{연구 결과}

\section{수술 7 개월 후 구개편도비대 아동과 일반 아동의 길항반복운동 소요시간 비교}

각 음절별로 수집된 자료를 바탕으로 독립된 두 집단 $t$-검정을 실 시하여 Table 2와 같은 결과를 얻을 수 있었다. 제시된 바와 같이/피/, 
Table 2. Comparison of the time required for DDK (unit, second)

\begin{tabular}{lccc}
\hline DDK & AT group (N=27) & TD group (N=29) & $t$ \\
\hline $\mathrm{p}^{\mathrm{h}} \Lambda$ & $3.361(.287)$ & $3.259(.158)$ & 1.627 \\
$\mathrm{t}^{\mathrm{h}} \Lambda$ & $3.278(.284)$ & $3.183(.204)$ & 1.438 \\
$\mathrm{k}^{\mathrm{h}} \Lambda$ & $3.580(.343)$ & $3.451(.291)$ & 1.522 \\
$\mathrm{c} \Lambda$ & $3.585(.324)$ & $3.526(.256)$ & .757 \\
$\mathrm{kuy}$ & $3.959(.322)$ & $3.962(.298)$ & -.037 \\
$\mathrm{p}^{\mathrm{h}} \Lambda \mathrm{t}^{\mathrm{h}} \Lambda \mathrm{k}^{\mathrm{h}} \Lambda$ & $3.238(.289)$ & $3.175(.341)$ & .746
\end{tabular}

Values are presented as mean (SD).

DDK= diadochokinesis; $A T$ = children 7 months after tonsillectomy; TD= typically developing children.

Table 3. Comparison of the PCC

\begin{tabular}{lccc}
\hline & AT group (N=27) & TD group $(\mathrm{N}=29)$ & $t$ \\
\hline PCC (\%) & $93.604(5.413)$ & $96.155(5.053)$ & -1.824 \\
\hline
\end{tabular}

Values are presented as mean (SD).

$\mathrm{PCC}=$ percentage of consonants correct; $\mathrm{AT}$ = children 7 months after tonsillectomy; $\mathrm{TD}=$ typically developing children .

Table 4. Comparison of phonological processes

\begin{tabular}{lcccc}
\hline Phonological process & $\begin{array}{c}\text { AT group } \\
(\mathrm{N}=27)\end{array}$ & $\begin{array}{c}\text { TD group } \\
(\mathrm{N}=29)\end{array}$ & $\chi^{2}$ & $p$-value \\
\hline $\begin{array}{l}\text { Whole-word process } \\
\quad \text { Typical intersyllabic cluster-simplification }\end{array}$ & 1 & 1 & .000 & 1.000 \\
$\begin{array}{l}\text { Segment-change process } \\
\text { Liquid simplification }\end{array}$ & 4 & 2 & .276 & .600 \\
$\quad$ Stopping of fricative or affricate & 3 & 0 & 1.566 & .211 \\
$\quad$ Affrication or palatalization & 2 & 0 & .596 & .440 \\
Interdentalization of fricative & 9 & 5 & 1.168 & .280 \\
Interdentalization of affricate & 1 & 3 & .198 & .656 \\
\hline
\end{tabular}

Values are presented as number of children produced phonological processes.

$\mathrm{AT}=$ children 7 months after tonsillectomy; $\mathrm{TD}=$ typically developing children.

/터/, /커/, /러/, /긍/을 각 15회 반복하는 과제와/퍼터커/를 5회 반복 하는 과제에서 모두 두 집단에 유의한 차이가 나타나지 않았다.

\section{수술 7 개월 후 구개편도비대 아동과 일반 아동의 자음정확도 비교}

두 집단의 자음정확도에 차이가 있는지를 비교하기 위하여 독립 된 두 집단 $t$-검정을 실시한 결과, Table 3 과 같은 결과를 얻을 수 있 었다. 이를 통하여 편도절제술 7 개월 후 아동은 일반 아동과 자음 정확도에 차이가 없는 것을 알 수 있었다.

\section{수술 7 개월 후 구개편도비대 아동과 일반 아동의 음운변동 비교}

두 집단 아동들이 보이는 말소리 오류에는 어떤 음운변동들이 나타나고, 그 빈도는 어떻게 다른지 알아보기 위하여 두 집단 아동
Table 5. Pearson correlation coefficient of DDK and PCC in AT group

\begin{tabular}{ll}
\hline $\mathrm{DDK}$ & PCC \\
\hline $\mathrm{p}^{\mathrm{h}} \Lambda$ & $-.401^{*}$ \\
$\mathrm{t}^{\mathrm{h}} \Lambda$ & -.296 \\
$\mathrm{k}^{\mathrm{h}} \Lambda$ & $-.438^{*}$ \\
$\mathrm{\Lambda} \Lambda$ & -.367 \\
$\mathrm{kum}$ & $-.575^{* *}$ \\
$\mathrm{p}^{\mathrm{h}} \Lambda \mathrm{t}^{\mathrm{h}} \Lambda \mathrm{k}^{\mathrm{h}} \Lambda$ & $-.449^{*}$ \\
\hline
\end{tabular}

$\mathrm{DDK}=$ diadochokinesis; $\mathrm{PCC}=$ percentage of consonants correct; $\mathrm{AT}=$ children 7 months after tonsillectomy.

${ }^{*} p<.05,{ }^{* *} p<.01$.

Table 6. PCC and PP in three children

\begin{tabular}{llccc}
\hline Step & & Child 1 & Child 2 & Child 3 \\
\hline Baseline & PCC (\%) & 88.1 & 86.6 & 77.1 \\
& PP & IF (6) & TS (6) & IF (9) \\
& & AP (3) & LS (4) & IA (7) \\
Post-therapy & PCC (\%) & SF (3) & & \\
& PP & Disappeared & Disappeared & IF (9) \\
& & & & IA (5) \\
Maintenance & PCC (\%) & Not tested & 98.6 & 88.6 \\
& PP & Not tested & Disappeared & IF (8) \\
& & & & IA (6) \\
\hline
\end{tabular}

$\mathrm{PCC}=$ percentage of consonants correct; $\mathrm{PP}=$ phonological processes (number of produced phonological processes); $\mathrm{IF}=$ interdentalization of fricative; $\mathrm{AP}=$ affrication or palatalization; $\mathrm{SF}=$ stopping of fricative or affricate; $\mathrm{TS}=$ typical intersyllabic cluster simplification; $\mathrm{LS}=$ liquid simplification; $\mathrm{IA}=$ interdentalization of affricate.

들에서 나타난 음운변동을 분석하여 $\chi^{2}$-검정을 시행하였으며, $\mathrm{Ta}-$ ble 4 와 같은 결과를 얻을 수 있었다. 제시된 바와 같이 편도절제술 7 개월 후 아동은 일반 아동에 비하여 좀 더 다양한 음소변화 변동 을 보였으며, 각각의 음운변동을 3 회 이상 나타낸 아동들의 수도 일반 아동에 비하여 조금 더 많았다. 그러나 이러한 차이는 통계적 으로 유의하지 않았다.

\section{수술 7 개월 후 구개편도비대 아동의 길항반복운동 소요시간과 자음정확도의 상관}

편도절제술 후 7 개월이 흐른 뒤 아동의 말운동 기능이 자음정확 도와 상관이 있는지 알아보기 위하여 이들의 길항반복운동 소요 시간과 자음정확도의 상관계수를 구해 보았다. 그 결과, Table 5 와 같은 결과를 얻을 수 있었다. 제시된 바와 같이 편도절제술 7개월 후 아동들은 수술 후/퍼/, /커/, /긍/과 /퍼터커/를 반복하는데 소요 된 시간이 수술 후의 자음정확도와 음의 상관관계를 가지는 것으 로 나타나, 해당 음소를 빠르게 반복하는 경우 자음정확도가 높은 경향이 있음을 알 수 있었다. 


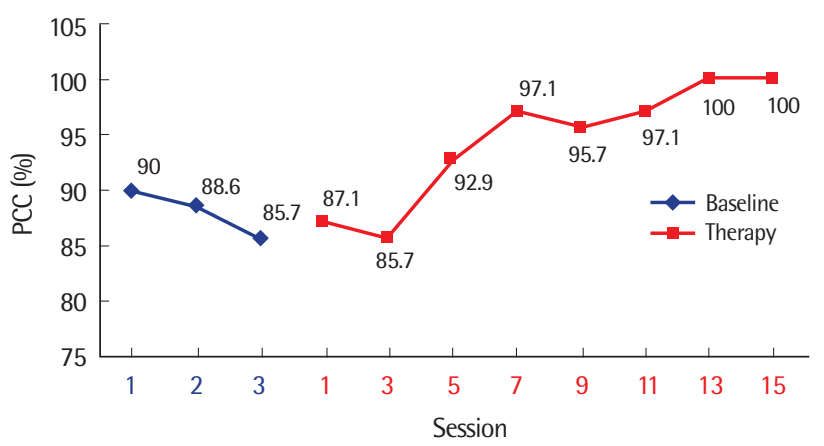

Figure 1. Percentage of consonants (PCC) correct contour in child 1.

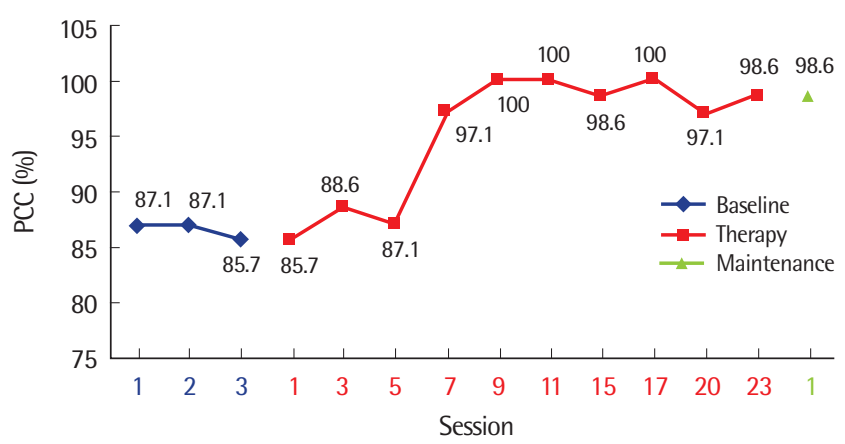

Figure 2. Percentage of consonants (PCC) correct contour in child 2.

\section{수술 7 개월 후 구개편도비대 아동의 조음 치료 결과}

편도절제술 7 개월 후 재평가 결과의 설명을 듣고 총 세 명의 아동 보호자가 자발적 치료 참여 의사를 보였다. 세 명의 아동은 각각 주 $1-2$ 회의 개별 조음 치료를 받았다. 1 회기의 치료 시간은 30 분씩이 었으며 치료 시작 전 기초선과 치료 후, 그리고 유지 시 자음정확도, 음운변동 변화추세는 Table 6과 같다.

치료 아동 1 (치료 시작 시 만 5세 7개월, 치료 종료 시 만 5세 11 개월)은 3 회의 기초선 후 약 4 개월간 총 15 회의 치료를 진행하였다. 개인 사정으로 주 1 회의 치료 스케줄로 진행하였으며, 주된 음운변 동은 치조마찰음의 치간음화, 파찰음화·경구개음화, 파찰음.마찰 음의 파열음화였는데 약 2 개월 후부터 3회 이상 나타나는 음운변 동 없이 유지되는 모습을 관찰할 수 있었다. 치료 종료 후 개인 사정 으로 유지 검사를 실시하지는 못하였다. 치료 아동 1 의 자음정확도 변화를 그래프로 살펴보면 Figure 1과 같다.

치료 아동 2 (치료 시작 시 만 6세 11 개월, 치료 종료 시 만 7세 2 개 월)는 3 회의 기초선 후 약 3 개월간 총 23 회의 치료를 진행하였다. 주 2 회의 치료 스케줄로 진행하였으며, 주된 음운변동은 전형적 어중 단순화, 유음의 단순화였는데, 약 2 개월 후부터 3 회 이상 나타나는

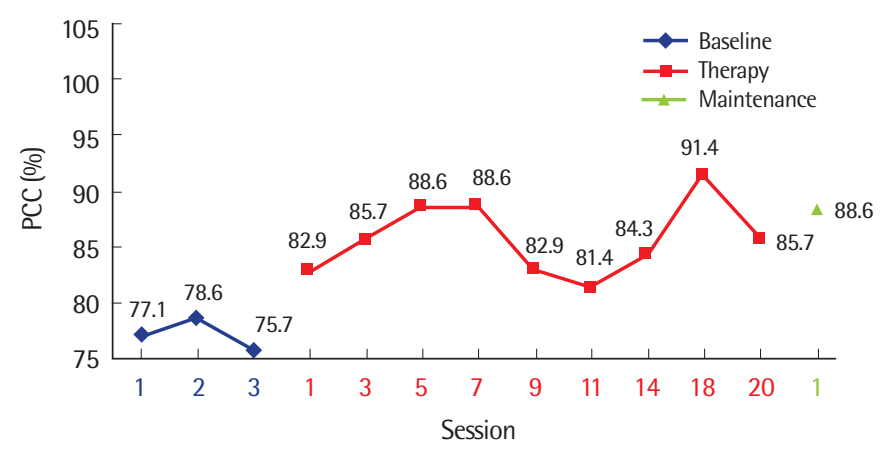

Figure 3. Percentage of consonants (PCC) correct contour in child 3.

음운변동 없이 유지되는 모습을 관찰할 수 있었다. 치료 종료 약 6 개월 후 유지 검사를 실시한 결과 치료 종료 시의 수준이 유지되고 있었다. 치료 아동 2의 자음정확도 변화를 그래프로 살펴보면 Figure 2 와같다.

치료 아동 3 (치료 시작 시 만 6세 9개월, 치료 종료 시 만 7세 3개 월)은 3 회의 기초선 후 약 6 개월간 총 20 회의 치료를 진행하였다. 개 인 사정으로 주 1 회의 치료 스케줄로 진행하였으며, 주된 음운변동 은 치조마찰음의 치간음화, 파찰음의 치간음화였는데, 치료를 종료 하는 시기에도 두 음운변동이 남아있었다. 또한 치료 종료 약 6 개월 후 유지 검사를 실시한 결과, 치료 후반에 나타나던 치조마찰음의 치간음화와 파찰음의 치간음화가 지속적으로 나타나고 있었다. 치 료 아동 3 의 자음정확도 변화를 그래프로 살펴보면 Figure 3과 같다.

\section{논의 및 결론}

본 연구는 1차 연구에서 나타났던 편도절제술 6주 후의 특성이 장기적으로 지속되는지, 약 7개월 정도의 비교적 긴 시간이 흐르면 또래와 유사한 수준으로 변화가 나타나는지, 그리고 변화가 없는 아동이 있다면 조음 치료로 개선이 되는지 알아보고자 하였다. 이 를 위하여 편도 절제술 7 개월 후 말운동 기능 및 조음음운 특성을 일반 아동과 비교하여 살펴보았다. 또한 수술 후 평가에서도 자음 정확도와 음운변동 특성이 또래 일반 아동 수준에 미치지 못하는 세 명의 아동에게 조음 치료를 실시하여 보았다.

연구 결과, 편도절제술 7 개월 후 구개편도비대 경력의 아동과 일 반 아동은 말운동 기능과 자음정확도, 그리고 음운변동의 빈도에 서 통계적으로 유의한 차이를 보이지 않았다. 즉 편도절제술을 시 행 받고 7 개월 정도의 시간이 지나면 구개편도비대의 경력이 있던 아동도 일반 아동과 유사한 수준이 된다는 것을 알 수 있었다. 이와 같은 결과는 편도절제술 후 2 년간 안면 자세, 근 긴장도, 저작, 삼킴, 
호흡 등과 관련된 근기능을 평가한 Valera 등(2006)의 연구 결과를 지지해준다. 연구자들은 40 명의 편도절제술을 시행 받은 아동들 을 대상으로 술 후 1 개월, 6 개월, 12 개월, 24 개월에 각각 술 전과 동 일한 평가를 실시하였다. 그 결과 술 후 1 개월에는 의미 있는 변화 를 보이지 않았지만 6 개월이 지난 후에는 모든 항목에서 유의한 진 전을 보였으며, 그 후로는 유의한 변화가 없었다. 본 연구의 1 차 연 구인 편도절제술 6주 후에는 DDK 소요시간을 제외하고 자음정확 도와 음운변동에 유의한 변화가 없었으나, 술 후 7개월과 같이 비교 적 긴 시간이 경과한 후의 2 차 연구에서 일반 아동 집단과 유사한 수준을 보인 점은 이들의 연구 결과와 같은 맥락으로 파악할 수 있 을 것이다.

한편, Lundeborg, McAllister, Samuelsson, Ericsson과 Hultcrantz (2009)는 4-5세의 구개편도비대 아동 67명과 일반 아동 47명을 비 교한 결과, 본 연구의 1 차 연구 결과와 같이 두 집단의 조음음운 수 준에 유의한 차이가 있음을 보여주었다. 그러나 편도절제술 6개월 후의 평가 결과 구개편도비대 경력의 아동들은 조음음운 수준에 진전이 있었음에도 일반 아동과의 격차는 더 벌어진 것으로 나타 났다. 연구자들은 구개편도비대 아동들이 수술 후 6개월이 지나면 서 조음음운에 개선이 보였지만 일반 아동을 따라잡기에는 충분 치 않았으며, 수술로 말소리 길의 변화를 유도하는 것만으로는 이 아동들의 음운체계에 변화를 유도하지는 못한 것으로 판단하였다.

이와 같이 유사한 연구들에서 비교적 다른 결과가 나온 것은 각 연구에 포함된 아동들의 개별적인 차이가 있었거나 또는 분석, 비 교 방식의 차이에 기인할 수 있는 것으로 여겨진다. 본 2차 연구에 서도 각 측정치인 길항반복운동에 소요되는 시간과 자음정확도에 서 구개편도비대의 경력이 있던 아동 집단은 일반 아동 집단에 비 하여 조금씩 낮은 수준을 보이고 있었다. 통계적 유의성은 없었지 만 각 측정 항목의 평균치가 이와 같이 조금씩 낮은 것은 구개편도 비대 경력의 아동들 중 일부 아동들이 수술 후 7 개월이 지나도 여 전히 낮은 수준을 보이는 것과 상관이 있을 것으로 여겨진다. 또한 본 연구는 두 집단 아동의 자음정확도 평균을 비교하거나, 음운변 동별로 3 회 이상 나타난 아동의 수를 비교하였다. APAC 검사 결과 해석의 특성상 6세 6 개월 이후의 아동들은 백분위수를 일반 아동 과 비교할 자료가 없기 때문에 수술 후 7개월의 피험자 중에서 이 시기에 해당하는 아동들의 백분위수는 짐작하는 수준에서 파악 해야 했다. 본 2 차 연구의 실험 집단 아동 중에서 수술 후 7 개월에 측정된 자음정확도의 백분위수가 동일 연령 아동들의 $10 \%$ ile 미만 에 해당하거나 해당할 것으로 추정되는 아동은 전체 27 명 중 8 명이 었다. 술 후 7 개월이 지나도 실험 집단 아동의 약 $30 \%$ 에 해당하는 아동들의 자음정확도는 또래 집단에 비하여 매우 낮은 것을 알 수
있다. 술 후 7 개월에 비교한 구개편도비대 아동과 일반 아동의 자음 정확도는 통계적으로 유의한 차이가 없는 결과가 나왔지만, 개별적 으로 살펴본 특성은 이와 같은 측면이 있는 것이다. Lundeborg 등 (2009)의 연구에서도 각 아동에게 나타나는 오류의 특성을 분류하 고각 오류를 차등화하여 비교하였기 때문에 수술 6개월 후 비교에 서 집단 사이의 차이가 더 벌어진 것으로 여겨진다. 이와 같이 편도 절제술 후 6 개월 이상이 경과한 상태의 비교에서 연구에 따라 상이 한 결과가 나타난 것은 아직 알 수 없는 다른 원인들도 작용할 수 있 겠지만, 각 연구에 포함된 아동들의 개별적인 특성, 그리고 집단을 비교하는 방식에 기인할 수 있을 것으로 추측되므로 향후 연구의 분석과 비교 방법을 다양화 하는 것의 필요성을 생각하게 해준다.

또한 편도절제술 7개월 후의 DDK 소요시간은 /터/와 /러/를 제 외하고는 대부분 자음정확도와 유의한 음의 상관을 보였다. 이는 편도절제술 6 주 후의 결과와 유사한 특성으로, 연구개와 혀 뒷부분 으로 만들어내는 소리들을 빠르게 반복 산출할수록 자음정확도 가 높게 측정된 것을 의미한다. 즉 편도절제술로 구조적 결함이 제 거되어 혀 뒷부분 움직임에 방해가 되던 큰 덩어리가 사라졌기 때 문에 그 부위 조음기관의 움직임이 용이해졌을 것으로 판단되며, 이러한 특성이 자음정확도와 상관이 있다는 것으로 해석할 수 있 을 것이다. Vayisoğlu, Görür, Özcan과 Güçlütürk (2010)는 편도절 제술 아동 50명을 대상으로 10 일간 통증 완화를 위한 조음 치료를 진행하였으며, 그 결과 조음 치료가 수술 후 통증 완화에 효과적임 을 보여주었다. 연구자들은 50 명의 대상자를 무작위로 세 집단으로 나눈 뒤, 집단별로 의학적 처치(항생제와 소염진통제 투여)만 진행, 의학적 처지와 연구개음이 포함된 낱말 산출 연습 진행, 그리고 의 학적 처치와 양순음 및 치조음이 포함된 낱말 산출 연습 진행을 각 각 실시하였다. 그 결과 의학적 처치와 함께 연구개음이 포함된 낱 말 산출 연습을 진행한 집단의 아동들이 통계적으로 유의하게 더 낮은 통증을 느낀 것을 알 수 있었다. 이는 편도절제술 후 조음 치료 가 통증 완화에 효과적일 수 있음을 제시했을 뿐 아니라, 말소리 개 선을 위한 조기 재활에 도움을 줄 수 있음을 고려하게 해준다. 즉 연구개음 산출 연습을 한 아동들이 편도절제술로 인한 통증을 덜 느꼈다는 점은 수술 부위와 가장 가까운 부위를 움직이는 조음 산 출 연습이 오히려 이 부위의 통증을 줄여주고, 더 나아가 보다 이른 말소리 산출을 유도할 수 있었을 것으로 추정하게 한다. 따라서 연 구개음이 포함된 $\mathrm{DDK}$ 에서 보다 빠른 반복이 가능한 아동들은 편 도절제술 후 통증이 비교적 덜 심하였고 그 결과 전반적인 자음정 확도의 개선에 긍정적인 영향을 미쳤을 가능성을 고려하게 해준다.

한편, 수술 7개월 후 평가에서도 또래에 비하여 낮은 자음정확도 를 보인 구개편도비대 경력 아동 세 명의 조음 치료 결과를 살펴보 
면, 개인에 따라 다른 특성을 보이는 것을 알 수 있었다. 치료 아동 1 과 치료 아동 2 는 약 3-4개월의 조음 치료로 자음정확도와 음운변 동의 개선이 이루어지는 것을 보여주었다. 그러나 치료 아동 3 은 약 6 개월의 조음 치료를 받았으나 자음정확도와 음운변동에서 현저 한 변화를 나타내지 못하였다. 거리 문제나 부모의 치료 동의 문제 로 편도절제술 7 개월 후 또래보다 낮은 수준을 보인 아동들을 모두 치료하지는 못했지만, 이 세 명의 치료 사례를 통하여 구개편도비 대 경력 아동 중 치료에 반응이 좋은 아동과 그렇지 못한 아동이 있 을 수 있다는 것을 알 수 있었다. 이는 일부 아동의 경우 편도절제술 만 시행하고 자연적인 말소리 개선을 기대하는 것은 충분한 말소리 향상에 적절하지 않을 수 있음을 보여주는 것으로 해석할 수 있을 것이다. 따라서 편도절제술 후 일정 기간이 지난 후에도 연령에 비 하여 오류가 지속되는 아동들의 경우 보다 적극적이고 다양한 치 료를 시도할 필요가 있음을 알 수 있다. Clark (2012)는 25명의 정상 성인을 대상으로 혀 근육의 네 가지 훈련방법을 4 주간 실시하였고, 그 결과 집단 간의 통계적 유의성은 나타나지 않았으나 혀 근육의 훈련 특이성을 관찰할 수 있었다. 이는 구개편도비대가 있는 상황 에서 또는 편도절제술 후에 유사한 혀 근육 훈련을 함으로써 혀의 위치를 바르게 유지하고 보다 정확한 조음 위치를 찾아가게 하는 데 도움을 줄 수 있다는 점을 고려하게 해준다. 또한 Umberger와 Johnston (1997)은 혀 내밀기가 있는 구강근육기능장애 아동의 조 음 치료에서 조음 치료뿐 아니라 구강근육기능 치료를 병행하는 것 이 보다 효과적이었음을 보고하였다. 이와 같은 점을 고려하면, 조 음음운장애가 있는 구개편도비대 아동의 치료에서 어떠한 접근이 가장 효과적일지 생각해 보게 하며, 추후 이와 관련한 연구가 지속 적으로 이루어져야 할 필요성을 느끼게 한다.

본 연구의 결과 구개편도비대 아동들은 혀 내밀기(tongue thrust) 가 직접 나타난 경우는 없었지만, 치간음화와 전방화의 특성이 비 교적 많이 나타나고, 편도절제술 이후에도 유지되는 아동들이 있 으며 치료 후에도 개선이 어려운 사례가 있다는 것을 알 수 있었다. Neiva와 Wertzner (1996)는 혀 내밀기(침이나 음식을 삼키는 동안 혀의 앞 또는 옆이 돌출되거나 혀가 치아에 강하게 접촉하는 것, 그 리고 편안한 자세에서도 입이 제대로 닫혀있지 않거나 혀의 위치가 올바르지 않은 증상)의 진단과 관련된 프로토콜을 제시하면서 이 와 같은 경우의 진단에 주의할 점을 정리하고 그 필요성을 강조하 였다. 또한 Ruscello, Douglas, Tyson과 Durkee (2005)는 대설증 (macroglossia) 아동의 사례를 보고하면서 휴식 시 혀 위치를 조절 해줌으로써 말소리 산출의 오류를 개선시킬 수 있음을 제시하여 주었다. 이와 같은 선행연구들의 결과를 참고하면, 편도절제술 후 일정 기간이 지났음에도 지속적으로 조음 오류나 지체된 음운변
동을 보이는 아동들의 특성은 오래된 구조적 문제에서 기인한 것 으로 유추할 수 있으며, 보다 다양한 조음 치료의 시도가 필요할 것 이라는 점을 알려준다. 이러한 발견점들은 구개편도비대 아동의 말 소리에 대한 이해를 도울 수 있을 뿐 아니라, 술 전 또는 술 후의 지 속적인 평가 시 유용하게 사용될 진단 프로토콜의 개발이나, 치료 의 가이드라인을 정리하는 것의 필요성을 알려준다.

구개편도비대 아동의 편도절제술 전, 후 조음음운 특성에 대한 연구는 해외의 보고 외에는 찾아보기 힘들다. 국내의 경우는 구개 편도와 아데노이드 비대 아동의 수술 전후 비음도 변화에 연구의 초점이 맞추어져 있었다(Kim, Song, Chang, Jeon, \& Kim, 2000). 본 연구를 통하여 정리된 말소리 특성과 관련된 결과들은 이와 관 련된 국내 초기 자료로서의 의미가 있으며, 언어병리학 분야 외에 도 특수교육이나 이비인후과학 분야에서 유용하게 사용될 자료가 될 수 있을 것이다. 임상의 언어치료사들이 조음음운장애 아동을 진단하고 치료할 때, 그리고 그 가족을 대상으로 상담을 실시할 때 이와 관련된 정보를 상기할 필요가 있을 것이며 필요 시 적절한 전 문가에게 의뢰할 수 있어야 할 것이다. 이는 조음음운장애 진단의 정확성, 치료의 효율성과 직접 관계가 있을 것이다.

1 차 연구에서 나타난 바와 같이 구개편도비대 아동의 조음음운 문제는 수술과 동시에 해결되지 않았으며, 술 후 7개월의 시간이 지 났어도 지속적인 문제를 보이는 아동들이 있었다. 또한 언어치료를 시행한 사례들 중에도 진전의 양상이 상이하였다. 이러한 점은 구 개편도비대를 가지고 있는 아동들의 편도절제술 필요성 여부 및 적 절한 제거 시기에 대한 연구, 그리고 술 후 언어치료의 필요성 및 그 방법들에 대한 연구의 필요성을 제기하여 준다. 추후 이와 같은 특 성을 가진 아동들의 조음음운장애 예방과 진단, 조음 치료 및 의학 적 치료의 방법 및 시기 등에 관한 후속 연구들이 요구된다.

\section{REFERENCES}

Bernthal, J. E., \& Bankson, N. W. (2004). Etiology/factors related to phonologic disorders. In J. E. Bernthal \& N. W. Bankson (Eds.), Articulation and phonological disorders (5th ed., pp. 139-200). Boston, MA: Pearson.

Chae, S. W., Choi, G., Hwang, K. S., Lee, D. J., Choi, C. S., \& Hwang, S. J. (2000).

The incidence and clinical symptoms of palatine tonsillar hypertrophy in elementary school children. Korean Journal of Otolaryngology-Head and Neck Surgery, 43, 1342-1345.

Clark, H. M. (2012). Specificity of training in the lingual musculature. Journal of Speech, Language, and Hearing Research, 55, 657-667.

Han, J. H., Sung, J. E., Sim, H. S., \& Lee, Y. M. (2013). Effects of speaking rate 
manipulation and the severity of dysarthria on speech intelligibility and acoustic parameters in persons with cerebral palsy. Journal of Speech \& Hearing Disorders, 22, 35-54.

Han, J. S., \& Sim, H. S. (2008). Comparisons of the percentage of correct consonants, speech intelligibility, and speech acceptability among children with cleft palate, children with functional articulation disorder, and normally developing children. Korean Journal of Communication Disorders, 13, 454476.

Kim, I. T., Song, S. Y., Jang, K. H., Jeon, J. H., \& Kim, H. J. (2000). The effect of tonsillectomy and adenoidectomy on nasality in children. Korean Journal of Otolaryngology-Head and Neck Surgery, 43, 615-619.

Kim, M. J., Pae, S., \& Park, C. I. (2007). Assessment of phonology for children (APAC). Incheon: Human Brain Research \& Consulting Co.

Kim, S. J., \& Shin, J. Y. (2015). Speech sound disorders. Seoul: Sigma Press.

Kim, S. W. (2009). The feature of articulation according to language age in mentally retarded children (Master's thesis). Kongju University, Gongju, Korea.

Kim, Y. T., Hong, G. H., Kim, K. H., Jang, H. S., \& Lee, J. Y. (2009). Receptive \& expressive vocabulary test (REVT). Seoul: Seoul Community Rehabilitation Center.

Lee, K. D. (2009). Otorhinolaryngology: head and neck surgery (Volume II). Seoul: Ilchokak.

Lundeborg, I., McAllister, A., Samuelsson, C., Ericsson, E., \& Hultcrantz, E. (2009). Phonological development in children with obstructive sleep-disordered breathing. Clinical Linguistics \& Phonetics, 23, 751-761.

Moon, H., \& Ha, S. (2012). Phonological development in toddlers with cleft palate and typically developing toddlers aged 12-24 months. Korean Journal of Communication Disorders, 17, 118-129.

Neiva, F. C., \& Wertzner, H. F. (1996). A protocol for oral myofunctional assessment: for application with children. International Journal of Orofacial Myology, 22, 8-19.
Ruscello, D. M., Douglas, C., Tyson, T., \& Durkee, M. (2005). Macroglossia: a case study. Journal of Communication Disorders, 38, 109-122.

Salami, A., Jankowska, B., Dellepiane, M., Crippa, B., \& Mora, R. (2008). The impact of tonsillectomy with or without adenoidectomy on speech and voice. International Journal of Pediatric Otorhinolaryngology, 72, 1377-1384.

Shin, M. J., Kim, J. O., Lee, S. B., \& Lee, S. Y. (2010). Speech Mechanism Screening Test (SMST). Seoul: Hakjisa.

Singh, I., Gathwala, G., Pathania, R., Singh, J., \& Yadav, S. P. (1994). Hypertrophic tonsils causing articulation defect. Indian Journal of Pediatrics, 61, 106-107.

Song, Y. (2014). Comparison of speech motor function, articulation, and phonological characteristics of children with and without palatine tonsil hypertrophy. Communication Sciences \& Disorders, 19, 540-550.

Song, Y., \& Sim, H. S. (2008). Compensation ability in speech motor control in children with and without articulation disorders. Speech Sciences, 15, 183-201.

Umberger, F. G., \& Johnston, R. G. (1997). The efficacy of oral myofunctional and coarticulation therapy. International Journal of Orofacial Myology, 23, $3-9$.

Valera, F. C., Travitzki, L. V., Mattar, S. E., Matsumoto, M. A., Elias, A. M., \& Anselmo-Lima, W. T. (2003). Muscular, functional and orthodontic changes in pre school children with enlarged adenoids and tonsils. International Journal of Pediatric Otorhinolaryngology, 67, 761-770.

Valera, F. C., Trawitzki, L. V., \& Anselmo-Lima, W. T. (2006). Myofunctional evaluation after surgery for tonsils hypertrophy and its correlation to breathing pattern: a 2-year-follow up. International Journal of Pediatric Otorhinolaryngology, 70, 221-225.

Vayisoğlu, Y., Görür, K., Özcan, C., \& Güçlütürk, T. (2010). Is speech therapy useful as a complementary treatment for post-tonsillectomy pain? International Journal of Pediatric Otorhinolaryngology, 74, 765-767. 


\section{국문초록}

\section{편도절제술 후 구개편도비대 아동과 일반 아동의 말운동 기능 및 조음음운 특성 비교}

\section{송윤경}

동명대학교 언어치료학과

배경 및 목적: 1 차 연구에서 구개편도비대 아동은 일반 아동에 비하여 길항반복운동 소요시간이 더 길고, 자음정확도가 더 낮으며, 음 운변동을 더 다양하게 보이는 것으로 나타났다. 편도절제술 6주 후 결과에서도 자음정확도와 음운변동은 같은 경향을 보였다. 이에 술 후 7개월이 흐른 후 이 변인들에 변화가 있는지 알아보기 위하여 일반 아동과 비교하여 보았다. 방법: 초기 평가 7개월 후, 선행연구에 참여하였던 구개편도비대 아동 27 명과 일반 아동 29 명을 대상으로 길항반복운동과 아동용 발음평가를 시행하여 비교하였다. 또한 평 가 결과, 여전히 지체된 자음정확도를 보인 아동 세 명을 대상으로 조음 치료를 시행하였다. 결과: 편도절제술 7개월 후 아동들은 길항 반복운동 소요시간, 자음정확도, 음운변동에서 일반 아동들과 유의한 차이를 보이지 않았다. 조음 치료 후 두 명의 아동은 개선을 보였 으나, 한 명의 아동은 개선을 보이지 않았다. 논의 및 결론: 편도절제술 후 7개월이면 구개편도비대 아동은 일반 아동의 수준을 따라잡 는 것을 알 수 있었다. 그러나 개별적인 특성상 이 시기에도 지체된 아동이 있으며, 치료 후 특성도 개인차가 있음을 알 수 있었다. 이는 구개편도비대가 말소리에 미치는 부정적 영향이 편도절제술 후에도 일부 지속될 수 있음을 알려준다. 편도절제술 시기 및 조음 치료의 필요성에 관한 추후 연구가 요구된다.

핵심어: 구개편도비대, 편도절제술, 길항반복운동, 자음정확도, 음운변동

본 연구는 2013년도 정부(교육부)의 재원으로 한국연구재단의 지원을 받아 연구되었음(NRF-2013S1A5A8024867).

\section{참고문헌}

김민정, 배소영, 박창일(2007). 아동용발음평가(APAC). 인천: 휴브알앤씨.

김수진, 신지영(2015). 말소리장애. 서울: 시그마프레스.

김시원(2009). 정신지체 아동의 언어연령별 조음특성. 공주대학교대학원 석사학위논문.

김영태, 홍경훈, 김경희, 장혜성, 이주연(2009). 수용·표현어휘력검사(REVT). 서울: 서울장애인종합복지관.

김익태, 송상윤, 장기현, 전진형, 김형종(2000). 소아에서 편도 및 아데노이드 적출술 후 비음도의 변화. 대한이비인후과학회지, 43, 615-619.

문희원, 하승희(2012). 12-24개월 구개열 유아와 일반 유아의 음운발달. 언어청각장애연구, 17, 118-129.

송윤경(2014). 구개편도비대 아동과 일반 아동의 말운동 기능 및 조음음운 특성 비교. 언어청각장애연구, 19, 540-550.

송윤경, 심현섭(2008). 조음장애아동과 비장애아동의 말운동통제 보상능력 비교. 음성과학, 15, 183-201.

신문자, 김재옥, 이수복, 이소연(2010). 조음기관 구조·기능 선별검사. 서울: 학지사 심리검사연구소.

이강대(2009). 이비인후과학: 두경부외과학 (II). 서울: (주)일조각.

채성원, 최진, 황규성, 이동진, 최충식, 황순재(2000). 초등학교 학생에서 구개편도 비대의 빈도와 임상증상에 대한 고찰. 대한이비인후과학회지, 43 , 1342-1345.

한지후, 성지은, 심현섭, 이영미(2013). 말속도 조절 및 중증도가 마비말장애 화자의 말명료도와 음향학적 파라미터에 미치는 영향. 언어치료연구, 22, 35-54.

한진순, 심현섭(2008). 구개열 아동과 일반 아동 및 기능적 조음장애 아동의 자음정확도, 말 명료도 및 말 용인도 비교. 언어청각장애연구, 13, 454476. 